\title{
PLICATE STAMINAL FILAMENTS IN TILLANDSIA SUBGENUS ANOPLOPHYTUM (BROMELIACEAE) ${ }^{1}$
}

\author{
Timothy M. Evans and Gregory K. Brown ${ }^{2}$ \\ Department of Botany, University of Wyoming, Laramie, Wyoming 82071-3165
}

\begin{abstract}
A B S T R A C T
Plication of staminal filaments is an important diagnostic character for Tillandsia subgenus Anoplophytum (ca. 45 species). The monophyletic integrity of subgenus Anoplophytum has recently been questioned, and we conducted an anatomical investigation of plicate staminal filaments to better characterize this putative synapomorphy. Developmental studies show that the filament plications, or folds, become visible during or soon after anthesis. Serial sections of preplication filaments and filaments in sequential stages of plication were prepared and observed with light microscopy. A uniform sequence of parenchyma cell collapse begins three to four cell layers out from the vascular bundle and proceeds centrifugally to the epidermis. Eventually the epidermal cells collapse, leaving only the vascular bundle and a few surrounding parenchyma cells intact. Above and below the zone of plication, all parenchyma and epidermal cells in the filament remain intact. Species traditionally placed in subgenera Tillandsia and Allardtia have been found with plicate staminal filaments that are anatomically and developmentally identical to those studied from subgenus Anoplophytum. Alone, staminal filament plication does not appear to be a good diagnostic character for subgenus Anoplophytum, and doubts concerning the monophylesis of this subgenus are reinforced. The functional significance of stamen filament plication remains unknown.
\end{abstract}

ANOPLOPHYTUM was originally proposed by Beer (1854) as a segregate genus of Tillandsia. Tillandsia stricta, a commonly cultivated taxon is the type species. Anoplophytum was later relegated to sectional status within Tillandsia by Grisebach (1864). Baker (1887) maintained Anoplophytum within Tillandsia but upgraded it to the rank of subgenus. Mez (1934) recognized the essence of subgenus Anoplophytum, as well as the six other subgenera of Tillandsia sensu Smith and Downs (1977). It was Smith (1935) who emended the typification of Anoplophytum and made the transversely plicate filaments diagnostic for the subgenus.

An examination of diagnostic characters for the seven Tillandsia subgenera (Smith and Downs, 1977) shows that these taxa are usually distinguished by only one or two characters.

\footnotetext{
${ }^{1}$ Received for publication 3 November 1988; revision accepted 4 April 1989.

We sincerely thank the collectors and institutions (Table 1) for providing the plant material utilized in this study. We also thank Dr. Matt Lavin for direction in the use of the rotary microtome and the techniques used in the preparation of plant material for thin sectioning. W. Dennis Clark, Amy Jean Gilmartin, Harry Luther, and John F. Utley provided many useful suggestions on the manuscript. This research was sponsored by National Science Foundation grants BSR-8607187, BSR-8708267, an NSF "Research Experiences for Undergraduates" award, and a research grant from the Bromeliad Society, Inc., to GKB, and by the Department of Botany, University of Wyoming.

${ }^{2}$ All correspondence.
}

This is clearly the case when comparing subgenus Anoplophytum with subgenus Allardtia, where the diagnostic features are identical except for 1) relative stamen length and 2) the occurrence of plicate staminal filaments. The monophyletic nature of subgenus Anoplophytum has been in question (Gilmartin, 1972; Brown and Gilmartin, unpublished data), and a morpho-anatomical study of the plicated filaments was conducted to better characterize the plication process associated with taxa from subgenus Anoplophytum. The gross morphological similarities between plicate staminal filaments and contractile roots were noted prior to the anatomical investigations. Consequently, mechanistic parallels between root contraction and filament plication processes received serious consideration. A secondary motive of this research was to evaluate the possible functional significance of plicate filaments.

MATERIALS AND METHODS-All flowers and buds used in this study were fixed in Carnoy's solution, as the primary use of this material was for chromosomal study. After a minimum of $24 \mathrm{hr}$, they were transferred to $70 \%$ ethanol and stored at or below $0 \mathrm{C}$. The collections acquired for use in this study (i.e., those with plicate filaments) were done so without prior knowledge as to their identification. The criterion for study was based solely on the oc- 
TABLE 1. Tillandsia species examined for plicate staminal filaments

\begin{tabular}{|c|c|c|}
\hline Species & $\begin{array}{c}\text { Subgenus } \\
\text { (Sensu Smith \& } \\
\text { Downs, 1977) }\end{array}$ & Voucher \\
\hline $\begin{array}{l}\text { T. aequatorialis } \\
\text { Lyman B. Smith }\end{array}$ & Allardtia & Cultivated, Denver Botanical Garden (RM) \\
\hline T. butzii $\mathrm{Mez}$ & Tillandsia & $\begin{array}{l}\text { Mexico, Edo. Chiapas Cultivated, Selby Botanical Garden (SEL } \\
80-1598 \text { ) }\end{array}$ \\
\hline $\begin{array}{l}\text { T. caput-medusa } \\
\text { E. Morren }\end{array}$ & Tillandsia & Cultivated, Selby Botanical Garden (SEL s.n.) \\
\hline T. gardneri Lindley & Anoplophytum & Brazil, Edo. Rio de Janeiro Martinelli 11575 (WS) \\
\hline $\begin{array}{l}\text { T. sceptriformis } \\
\text { Mez \& Sodiro ex Mez }\end{array}$ & Allardtia & Ecuador, Prov. Pichincha Bravo 870 (WS) \\
\hline $\begin{array}{l}\text { T. stricta } \\
\text { Solander in Sims }\end{array}$ & Anoplophytum & Brazil Cultivated, Selby Botanical Garden (SEL 75-86-68) \\
\hline $\begin{array}{l}\text { T. xiphioides } \\
\text { Ker-Gawler }\end{array}$ & Anoplophytum & Argentina, Prov. Salta Palaci 207 (WS) \\
\hline
\end{tabular}

currence of plicate staminal filaments. One collection for each of the seven species (Table 1) was studied anatomically.

The filaments were dissected from anthesis stage flowers and buds of varying age, dehydrated in a graded ethanol series to $100 \%$ ethanol, and stained with eosin. They were then infiltrated with xylene, then paraplast, and finally embedded in paraplast.

Serial sections were cut at $7 \mu \mathrm{m}$ on a rotary microtome. The sections were afixed to slides with Haupt's solution, stained with safranin, then with fast green as a counter stain, and mounted in Permount. Photographic documentation was with Kodak Tech Pan 2415 film.

The filaments for scanning electron microscopy (SEM) were first hydrated, using a graded ethanol series, and then put through an osmium tetroxide-thiocarbohydrazide-osmium tetroxide (OTO) series (Brown and Gilmartin, 1989). They were dehydrated in a graded ethanol series, critical-point dried, mounted on SEM stubs, and sputter-coated with gold.

The scanning electron microscopy was done on a JEOL JSM-35C at the University of Wyoming. Photographic documentation was with Polaroid Type 665 film.

RESULTS-Plicate filaments were found to be present in species traditionally classified in subgenera Tillandsia and Allardtia as well as Anoplophytum (Table 1). There was no observable variation in the anatomical development of the plications within the different subgenera.

Plication, or folding, of the filament occurs during or soon after anthesis. Plication formation appears to be a direct result of cell collapse within the filament (Fig. 1-4). As the parenchyma and epidermal cells collapse, we speculate that structural support provided by those cells declines, causing the filament to bend. The possibility that plication causing compressional forces are generated by filament elongation below the region of plication was investigated. However, no evidence for this type of plication mechanism was found.

Parenchyma cell collapse is first visible three to four cell layers from the vascular bundle (Fig. 5). The collapsing region expands centrifugally, leaving large intercellular spaces (Fig. 6). Eventually even the epidermal cells collapse, leaving only the vascular bundle, a few parenchyma cells near the vascular bundle, and the cuticle still intact (Fig. 7). The remaining intact parenchyma are more intensely stained with safranin than are preplication parenchyma cells.

Collapse of transverse cell walls is the first visible sign of cell collapse (Fig. 8). As the transverse walls collapse inward, the radial and tangential walls fold along the longitudinal axis in an accordionlike manner. This results in an overall decrease in cross-sectional area of the cells, but there is no initial decrease in cell length. It is not until the vascular bundle bends, crushing some of the cells, that there is a decrease in the length of any of the cells. This transverse collapse of parenchyma cells not only causes longitudinal wrinkling in the radial and tangential cell walls, but also on the surface of the fully plicated filament (Fig. 9).

As the parenchyma cells collapse, the vascular bundle begins to bend within the intercellular spaces created by the adjacent collapsing cells. The initial collapse of the cells causes transverse wrinkles in the epidermis (Fig. 10), but the bends in the vascular bundle are not internally visible until later in the plication 

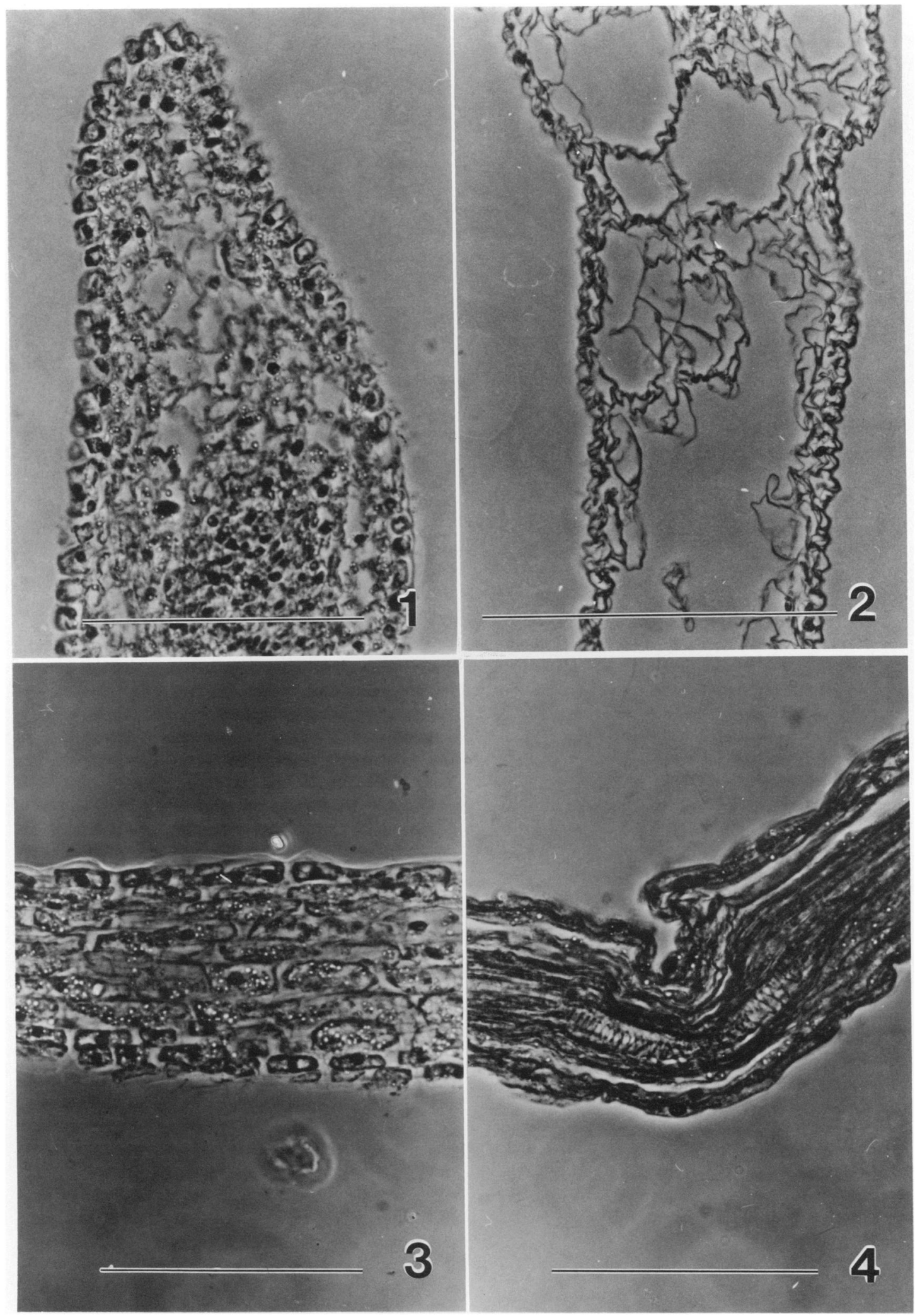

Fig. 1-4. Bar $=1 \mathrm{~mm}$. 1. Cross section of $T$. sceptriformis before plication. 2. Cross section of $T$. butzii after plication. 3. Longitudinal section of $T$. sceptriformis before plication. 4. Longitudinal section of $T$. xiphioides after plication. 

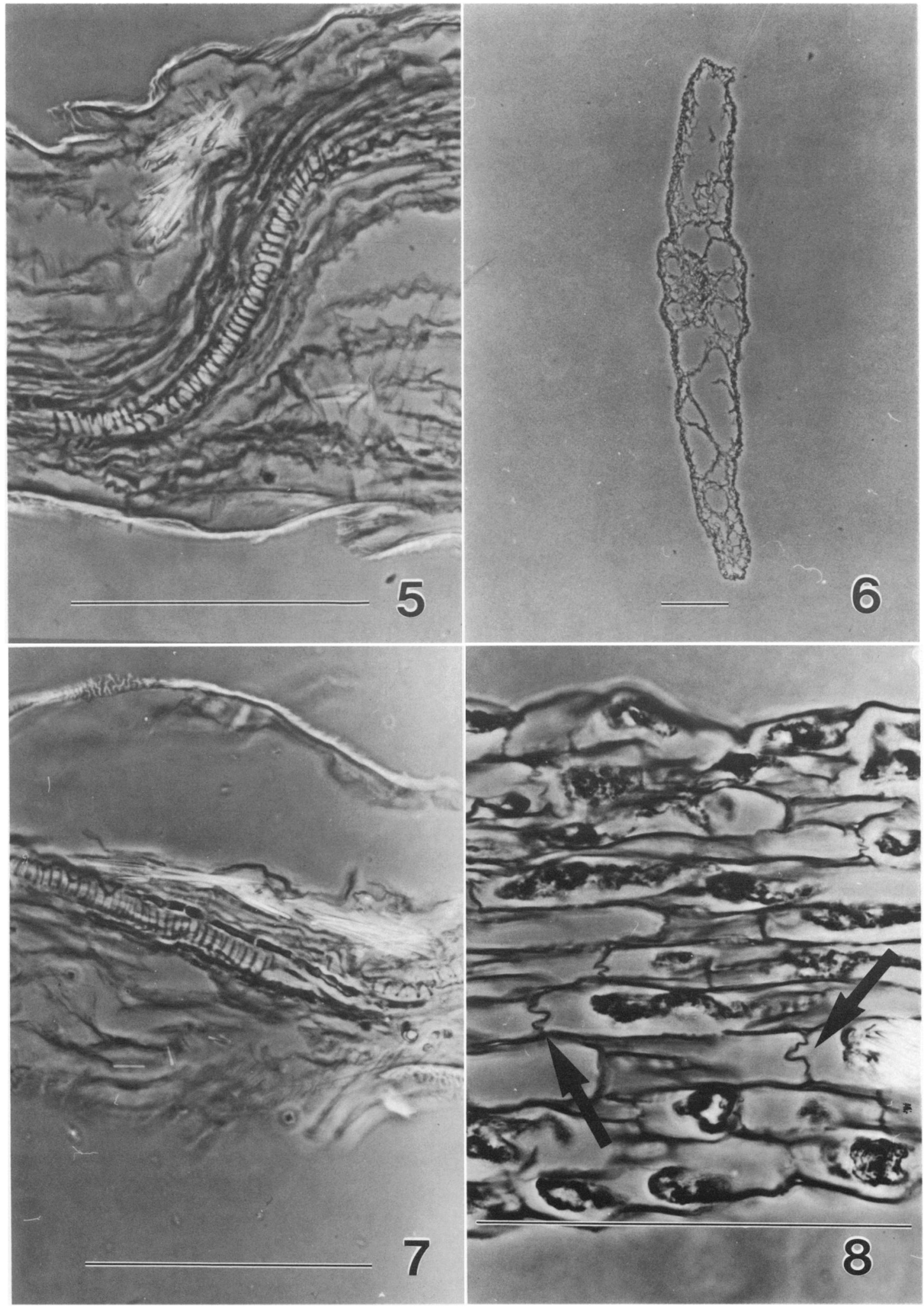

Fig. 5-8. Bar $=1 \mathrm{~mm}$. 5. Cell collapse beginning 3 to 4 cell layers from vascular bundle in $T$. butzii. 6. Large intercellular spaces caused by the collapsing parenchyma cells in $T$. butzii. 7. Cell collapse in $T$. butzii is complete, leaving only the vascular bundle, the cuticle, and a few parenchyma cells intact. 8. Transverse cell walls collapsing in $T$. butzii (arrows indicate collapsing transverse walls). 


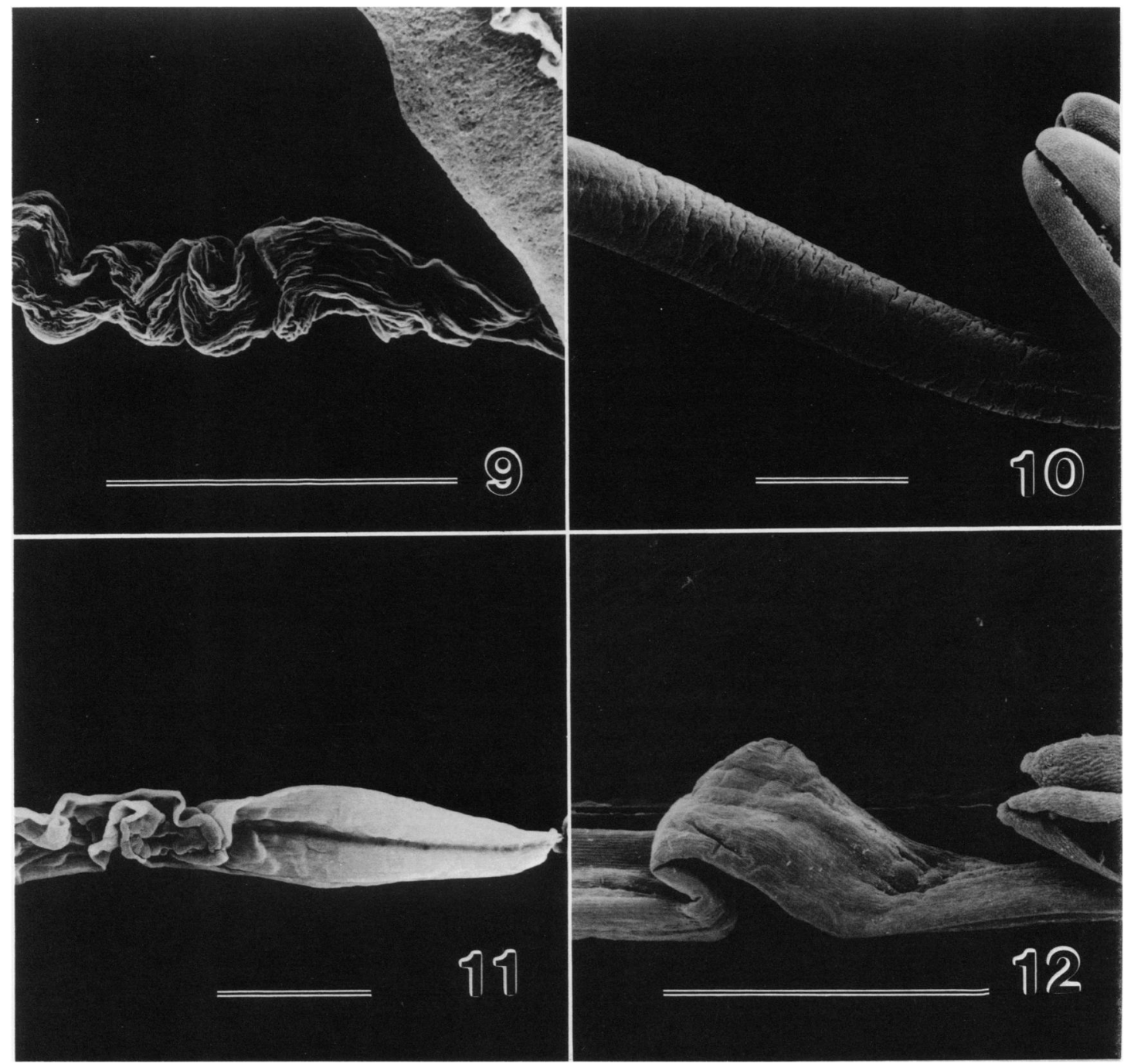

Fig. 9-12. Bar $=1 \mathrm{~mm}$. 9. Plicated $T$. aequatorialis filament with longitudinal wrinkles on surface. 10. Early plication in $T$. aequatorialis. Plications first become visible as transverse wrinkles in the epidermis. 11. Plicated $T$. stricta filament. Plicated area is 3 to $4 \mathrm{~mm}$ below anther. 12. Plicated T. gardneri filament. Plicated area is 1 to $2 \mathrm{~mm}$ below anther.

process. As more cells collapse, the transverse wrinkles give way to longitudinal wrinkles, and the vascular bundle begins to bend, until plication is complete. The plication events described here appear to be the same for each of those taxa listed in Table 1.

Although the plicated area of the filament is shortened due to the bending of the vascular bundle, the filament as a whole continues to elongate (Table 2). After plication, elongation continues in the filament below the plicated area. The length of the filament above the plicated region, if any, as well as the plicated area itself(once plication is complete) remains fairly constant (Table 2). Notice that for different species the plicated area is not always on the same region of the filament. In $T$. stricta the plicated area is 3 to $4 \mathrm{~mm}$ below the anther, while in $T$. gardneri plication occurs 1 to $2 \mathrm{~mm}$ below the anther (Fig. 11, 12).

Discussion-There are striking external similarities between plicate staminal filaments and contractile roots in general. Thus we compared contractile root growth mechanisms with the suspected contractile process in plicate staminal filaments. Several mechanisms have been proposed for contractile roots. Wilson and Honey (1966), for example, propose that root contraction in Hyacinthus orientalis is caused by the radial expansion and longitudinal contraction of inner parenchyma cells. 
Ruzin (1979) describes root contraction in Freesia (Iridaceae) to be the result of radially expanding outer parenchyma cells, with no longitudinal contraction taking place. Still another mechanism of root contraction was proposed by Thoday $(1926,1931)$ for Oxalis incarnata. He states that contraction is caused by the collapse of transverse zones of cells. According to this model, transverse zones of cells collapse as a result of a water deficit. As water is lost through the transpiration stream or absorbed by the bulb, certain layers of parenchyma cells collapse. The unequal distribution of turgid and collapsed layers causes the stele to bend. Smith (1930) suggested a similar model for the contraction of Brodiaea lactea roots. In that case, transverse layers of cells collapse, but prior to collapse all the parenchyma cells expand radially and shorten longitudinally. The actual cause of cell collapse was not determined.

One requirement of any proposed mechanism for plication is that it accounts for enough force to cause the vascular bundle to bend. Thoday (1931) observed that the bending of the vascular cylinder in contractile roots will not occur if the parenchyma cells directly adjacent to it remain turgid. Only if these cells collapse will the stele be able to bend. In plicate filaments, however, the vascular bundle starts bending even though most of the cells next to it remain turgid. We do not know whether compressional forces within the filament vascular bundle or loss of ground tissue support, or a combination of the two are ultimately responsible for plication.

With respect to the plicated region on the filament, plication is a contractile process. We are not certain if the staminal filament plication described here is unique. To our knowledge, however, contractile processes that are analogous to those of contractile roots have not been previously known in floral structure.

The functional role of plicate staminal filaments in pollination biology is not clear. Prior to this investigation, it was hypothesized (Brown, unpublished data) that plication served as a mechanism to draw dehiscent anthers back to the level of the stigma as a self pollination mechanism. The manifestation of filament plication at mid- to late-anthesis is consistent with this initial hypothesis. However, observations and measurements of the positional relationship between the anthers and stigma throughout anthesis do not support this idea (i.e., pre- and postanthesis anthers and stigma maintain more or less fixed positions relative to one another). Any decrease in filament length due to plication is more than compensated for
TABLE 2. Effect of plication on filament length

\begin{tabular}{ccc}
\hline \hline Species & $\begin{array}{c}\text { Total filament } \\
\text { length }(\mathrm{mm})\end{array}$ & $\begin{array}{c}\text { Base of plication } \\
\text { to base of } \\
\text { filament }(\mathrm{mm})\end{array}$ \\
\hline T. aequatorialis & & \\
Preplication & 13.5 & 7.5 \\
Postplication & 36.0 & 30.0 \\
$T$. sceptriformis & & \\
Preplication & 5.5 & 3.0 \\
Postplication & 10.0 & 6.0 \\
$T$. stricta & & \\
Preplication & 8.0 & 4.0 \\
Postplication & 13.0 & 8.0 \\
\hline
\end{tabular}

by elongation in the proximal, nonplicate portion of the filament (Table 2).

Other observations that may serve to help elucidate the role of plication in pollination include 1) plicate regions are notably elastic. Tension on the stamen with forceps will draw out the plicate region, and upon release the anther will "snap" back to its previous position, the plications being restored. 2) Collectively, the pleatlike folding of the filaments may form a pluglike barrier within the floral tube. This may retard evaporation of nectar.

The central most important difference between Tillandsia subgenera Allardtia and Anoplophytum (sensu Smith and Downs, 1977) is the length of the stamen relative to petal claw length. In subg. Allardtia the stamen exceeds its respective petal claw and is more or less equal to the total petal (claw + blade) length. In subg. Anoplophytum the stamen is shorter relative to its petal, being more or less equal to the petal claw in length. Of the 46 species in the subgenus (Table 3), 27 are known to have some degree of filament plication. Three species ( $T$. ixioides, $T$. meridionalis, $T$. xiphioides) are described as having non-plicate filaments, though Luther (personal communication) has occasionally observed plicate filaments in $T$. meridionalis. Descriptive morphology of staminal filaments is lacking for the remaining 11 species of subg. Anoplophytum (Table 3).

We were surprised to discover that over half of the species with plicate filaments examined in this study (Table 1) are not members of subgenus Anoplophytum. This dramatically underscores the fact that most bromeliad species are woefully lacking in descriptive floral morphology (see Brown and Gilmartin, 1984, for more discussion of this issue). For example, there is no descriptive account for the androecium in T. aequatorialis; T. butzii and T. caputmedusa are simply described as having an- 
TABLE 3. Filament plication in Tillandsia subgenus Anoplophytum $^{\text {a }}$

\begin{tabular}{|c|c|}
\hline Taxon & Filament condition \\
\hline $\begin{array}{l}\text { T. aeranthos (Loiseleur) } \\
\text { Lyman B. Smith }\end{array}$ & plicate \\
\hline T. albertiana $\mathrm{F}$. Vervoorst & unknown \\
\hline$T$. araujei $\mathrm{Mez}$ in Martius & plicate \\
\hline T. arequitae (André) André & unknown \\
\hline T. argentina $\mathrm{C} . \mathrm{H}$. Wright & plicate \\
\hline T. bergeri $\mathrm{Mez}$ & faintly plicate \\
\hline${ }^{\mathrm{b}} T$. bermejoensis Hromadnik & straight \\
\hline T. brachyphylla Baker & unknown \\
\hline${ }^{\circ} T$. buchlohii Rauh & plicate \\
\hline T. caulescens Brongn. ex Baker & plicate \\
\hline${ }^{\circ} T$. chiltensis Rauh & straight \\
\hline T. diaguitensis Castell. & unknown \\
\hline T. didisticha (E. Morren) Baker & plicate \\
\hline $\begin{array}{l}\text { T. esseriana Rauh \& Lyman B. } \\
\text { Smith }\end{array}$ & unknown \\
\hline T. friesii $\mathrm{Mez}$ & unknown \\
\hline T. gardneri Lindley & plicate \\
\hline $\begin{array}{l}\text { T. geminiflora Brongn. in } \\
\text { Duperrey }\end{array}$ & plicate \\
\hline T. geissei R. A. Philippi & unknown \\
\hline T. globosa Wawra & $\begin{array}{l}\text { slightly if at } \\
\text { all plicate }\end{array}$ \\
\hline${ }^{\mathrm{b}} T$. grazielae Ruby Braga \& Sucre & straight \\
\hline T. heteromorpha $\mathrm{Mez}$ & unknown \\
\hline${ }^{\mathrm{b}} T$. horstii Rauh & unknown \\
\hline T. ixioides Griseb. & straight \\
\hline T. jucunda Castell. & plicate \\
\hline$T$. linearis Vell. Conc. & unknown \\
\hline T. lorentziana Griseb. & plicate \\
\hline T. macbrideana Lyman B. Smith & straight \\
\hline T. meridionalis Baker & plicate \\
\hline T. montana Reitz & $\begin{array}{l}\text { linear, } \\
\text { contorted } \\
\text { near apex }\end{array}$ \\
\hline${ }^{\mathrm{b}} T$. muhrae W. Weber & unknown \\
\hline$T$. nana Baker & unknown \\
\hline T. neglecta E. Pereira & straight \\
\hline T. nuptialis Ruby Braga \& Sucre & plicate \\
\hline T. pohliana Mez in Martius & plicate \\
\hline${ }^{\mathrm{b}} T$. pseudomacbrideana Rauh & plicate \\
\hline T. reclinata Pereira \& Martinelli & unknown \\
\hline T. rosea Lindley & plicate \\
\hline T. seideliana E. Pereira & plicate \\
\hline $\begin{array}{l}\text { T. sprengeliana Klotzsch ex Mez } \\
\text { in Martius }\end{array}$ & unknown \\
\hline T. stricta Sol. in Sims & plicate \\
\hline T. stricta Sol. var. albifolia & plicate \\
\hline T. sucrei E. Pereira & plicate \\
\hline$T$. tenuifolia $\mathrm{L}$. & plicate \\
\hline${ }^{\mathrm{b}} T$. toropiensis Rauh & plicate \\
\hline$T$. vernicosa Baker & plicate \\
\hline T. xiphioides Ker-Gawler & $\begin{array}{l}\text { filiform, } \\
\text { straight }\end{array}$ \\
\hline
\end{tabular}

a Sensu Smith and Downs (1977) and taxa subsequently described.

b Author did not explicitly place into subgenus Anoplophytum in original citation. droecia of exserted stamens while $T$. sceptriformis has stamens included. Since Smith (1935) assigned plicate staminal filaments as diagnostic for subgenus Anoplophytum, this character state appears to have been associated only with taxa from Anoplophytum. Our finding of plicate filaments in species traditionally placed in other Tillandsia subgenera erodes the diagnostic value of this character and reflects the more profound problems of subgeneric circumscriptions within Tillandsia.

Developmentally, filament plication is viewed as a terminal character (Løvtrup, 1978). In light of hypotheses elaborated by Takhtajan $(1954,1972)$ and more recently presented by Tucker (1984), terminal floral characters would most likely have diagnostic utility at the specific or intraspecific categories of the taxonomic hierarchy. This interpretation would again suggest an overemphasis on filament plication as diagnostic at the subgeneric level.

Filament plication appears to be a complex growth/degenerative process. However, there are no direct data to address the genetic foundation for the character. New observations of variability in the occurrence of plicate filaments suggests a rather simple genetic basis for the character. Read (1988) makes a brief report on morphological variation in $T$. bergeri, and mentions that plications were not found in some flowers, while indications of filament plication were observed in others. Smith and Downs (1977) describe $T$. bergeri as having "filaments faintly plicate." In $T$. xiphioides the occurrence of plicate filaments is variable. Smith and Downs (1977) describe $T$. xiphioides as having "filaments filiform, straight" (Table 3). We find full manifestation of plication in the Palaci 207 collection (Table 1) as well as in commercially available cultivated material.

Muddling the interpretation of the plicate filament as a diagnostic character are data from a recent survey of bromeliad stigma morphology that reveals a stigma type that correlates strongly with the established Anoplophytum diagnostic characters. Brown and Gilmartin (1989) have reported on the stigma morphology type for 13 species from subg. $A n$ oplophytum, and have found all but two of the species (i.e., $T$. linearis, $T$. xiphioides) to have the simple erect stigma type (see Brown and Gilmartin, 1984, for definitions of stigma type categories). The $T$. linearis collection and one of the two $T$. xiphioides collections examined had conduplicate-spiral stigmas. The other collection of $T$. xiphioides had the simple-erect stigma form. Mez (1934) also illustrates the simple-erect form for T. xiphioides. Again, $T$. 
xiphioides with plicate and nonplicate filaments, stamens either included or exserted, style exserted, and broad petal blades (all traits of other subgenera) appears to be problematic in subg. Anoplophytum (sensu Smith and Downs, 1977).

Alone, the simple-erect stigma type is not diagnostic for subg. Anoplophytum, since this stigma type is found in species from other Tillandsia subgenera. The same is also true for plicate staminal filaments. The correlation of 1) included stamens equal to the petal claw in length; 2) plicate filaments; and 3) simple-erect stigmas may provide a base for continued recognition of subg. Anoplophytum. However, with the discovery of plicate filaments in taxa from subg. Allardtia, the potential exists for plicate filament/simple-erect stigma correlations within other parts of Tillandsia. Thus, the dis tinction between subgenera Anoplophytum and Allardtia becomes more vague.

The occurrence of plicate staminal filaments can no longer be viewed as a primary diagnostic character for Tillandsia subgenus Anoplophytum as it is currently recognized, and monophylesis of the entire subgenus seems unlikely. Ongoing studies of tillandsioid floral morphology and its variation are beginning to fill some of the conspicuous morphological data voids. As this data base grows, a taxonomy that better reflects phylogeny becomes more of a reality.

\section{LITERATURE CITED}

BAKER, J. G. 1887. Synopsis of Tillandsieae. J. Bot. 25: 212.

BEER, J. G.. 1854. Versuch einer Eintheilung der Familie der Bromeliaceen nach ihrem Blüthenstande. Flora 37: 346-349.

Brown, G. K., AND A. J. Gilmartin. 1984. Stigma structure and variation in Bromeliaceae-neglected taxonomic characters. Brittonia 36: 364-374.

$\longrightarrow-$ AND $\longrightarrow$ 1989. Stigma types in Bromeliaceae-a systematic survey. Syst. Bot. 14: 110-132.

Gilmartin, A. J. 1972. The Bromeliaceae of Ecuador. Phaner. Monogr. 4: 1-255. J. Cramer, Lehre, Germany.

Grisebach, A. H. R. 1864. Bromeliaceae. Flora of the British West Indian Islands, 590-599. Lovell Reeve, London.

Løvtrup, S. 1978. On von Baerian and Haeckelian recapitulation. Syst. Zool. 27: 348-352.

Mez, C. 1934. Bromeliaceae. In A. Engler, Das Pflanzenreick 4 (32): 1-667.

READ, R.W. 1988. Tillandsia bergeri, a many-splendored species. J. Bromeliad Soc. 38: 147-149.

Ruzin, S. E. 1979. Root contraction in Freesia (Iridaceae). Amer. J. Bot. 66: 522-531.

SMITH, F. H. 1930. The corm and contractile roots of Brodiaea lactea. Amer. J. Bot. 17: 916-927.

Smith, L. B. 1935. Studies in the Bromeliaceae VI. Proc. Amer. Acad. Arts 70: 147-220.

- AND R. J. Downs. 1977. Bromeliaceae (Tillandsioideae). Flora Neotropica Monogr. 14: 663-1492.

TAKHTAJAN, A. 1954. Quelques problèmes de la morphologie evolutive des angiospermes. Essais de botanique. Vopr. Bot. 2: 763-793.

-1972. Patterns of ontogenetic alterations in the evolution of higher plants. Phytomorphology 22: 164 171.

ThoDAy, D. 1926. The contractile roots of Oxalis incarnata. Ann. Bot. (London) 40: 571-583.

1931. Mechanism of root contraction in Brodiaea lactea. Pl. Physiol. (Lancaster) 6: 721-725.

TUCKER, S. C. 1984. Origin of symmetry in flowers. In R. White and W. Dickinson [eds.], Contemporary problems in plant anatomy, 351-395. Academic Press, New York.

Wilson, K., AND J. N. Honey. 1966. Root contraction in Hyacinthus orientalis. Ann. Bot. (London) n.s. 30: 47-61. 